\title{
THE EFFECT OF BRAND TRUST AND UNIVERSITY REPUTATION ON STUDENT'S DECISION TO CHOOSE MANAGEMENT STUDY PROGRAM IN THE FACULTY OF ECONOMICS AND BUSINESS UNIVERSITAS MUHAMMADIYAH SUMATERA UTARA
}

\author{
${ }^{1}$ Nel Arianty, ${ }^{2}$ Julita \\ ${ }^{1,2}$ Faculty of Economics and Business, Universitas Muhammadiyah Sumatera Utara
}

\begin{abstract}
This study aims to determine the effect of brand trust and university reputation on purchasing decisions, namely student decisions in choosing the Management Study Program at the UMSU Faculty of Economics and Business. The approach taken in this research is to use an associative approach, namely research that seeks to examine how a variable has a relationship or relationship with other variables. Sampling was carried out by non-probability sampling technique, and by incidental sampling approach. The population in this study were all students of the 2018/2019 UMSU Management Study Program, and the sample used in this study amounted to 126 respondents using the slovin technique. Data were collected by questionnaire method. The data analysis technique used multiple linear regression, classical assumption test, $t$ test, $F$ test and coefficient of determination. The results showed that the brand trust variable had a significant effect on purchasing decisions, and the university reputation variable had a significant effect on purchasing decisions. Based on the simultaneous test, the variable brand trust and university reputation have a significant effect on purchasing decisions.
\end{abstract}

Keywords: Brand Trust, University Reputation, and Purchase Decision

\section{PRELIMINARY}

The large number of universities in Indonesia shows the increasingly fierce competition in the world of educational services, both at the level of private universities and public universities. In addition to the growth of competition in the country, globalization has also encouraged the emergence of very competitive competition in the world of educational services throughout the country (Handayani, 2017). Universities are competing to develop all their potential and ability to compete in order to attract prospective students.

The creation of student decisions in choosing universities and existing study programs can be caused by various supporting factors such as the important role of the brand trust factor (Adiwidjaja \& Tarigan, 2017), service quality, operational costs, facilities, achievements and also reputation owned. The purchase decision is an action taken by consumers.

Basically, the reputation of the university has an important role for consumers in choosing and considering continuing their studies at a university, for that a good relationship between the university and consumers must be established. Reputation is not just a good relationship with the community but reputation is also a result information processing that is influenced by various cues itself, the work environment and colleagues, the media and most importantly also from personal experience with the organization (Warta, 2017, p. 14).

There is a public perception that assesses the quality of universities run by the private sector is low, until the assessment at the time of graduation and in obtaining work in the field, which is only because the university is not organized by the government. This has led to some speculation as to whether it is true that the quality of the university is of low value or is it just a lack of education and

International Journal of Economic, Business, Accounting, Agriculture Management and Sharia Administration |IJEBAS

E-ISSN: 2808-4713 | https://radjapublika.com/index.php/IJEBAS 
The Effect of Brand Trust and University Reputation on Student's Decision to Choose Management Study Program in The Faculty of Economics and Business Universitas Muhammadiyah Sumatera Utara Nel Arianty, Julita

information that is obtained and provided to the public.

\section{THEORETICAL BASIS \\ Buying decision}

Purchasing decision is a process of solving the problem of selecting from two or more alternative purchasing decision choices (Schiffman \& Kanuk, 2007). Consumer decisions are consumer actions in deciding a product that is considered a solution to the needs and desires of these consumers (Fahmi, 2016, p. 57).

There are several factors that can influence purchasing decisions according to (Arianty, Laili, Christiana, \& Jasin, 2016, p. 49), namely, cultural factors, social factors, personal factors and psychological factors.

The following is an explanation of the description of the purchasing decision-making process according to (Arianty, Laili, Christiana, \& Jasin, 2016) namely, the need for introduction, information seeking, evaluation of alternatives, purchase/purchase decisions, post-purchase behavior.

There are three indicators of purchasing decisions according to Kotler (Ansari, Hurriyati, Gaffar, Adi, \& Amanah, 2017) namely, perceived needs, activities before buying, wearing behavior, and post-purchase behavior.

\section{Brand Trust}

The existence of brand trust is based on consumer experience with the brand, namely with a process based on experience that has been experienced while using certain Costale products (Rahmawati, 2017). Brand trust is defined as the customer's desire to rely on a brand with the risks faced because the expectations of the brand will lead to positive results, Lau and Lee (Adiwidjaja \& Tarigan, 2017).

Factors that influence brand trust according to Lau and Lee (Fauziyah, 2016), namely, brand characteristics, company characteristics, customer brand characteristics. The indicators of brand trust according to Delgado (Bastian, 2014) are, brand reliability, and brand intentions.

\section{University Reputation}

Reputation is the assessment of interested parties which is used as the main argument in making choices, reputation is a good name that creates authority and makes the institution respected so that it is an important asset for institutions to survive and develop, reputation provides great benefits when facing turmoil and environmental dynamics, especially in neutralizing or reduce the impact of the crisis, (Warta, 2017, p. 194).

Image is reputation and achievement, although the image is something abstract and cannot be measured systematically, its shape can be felt from the results of good and bad research that comes from the public or the wider community. This assessment can be related to taste respect, a good impression rooted in the values of trust (Radiman, Gunawan, Wahyuni, \& Jufrizen, 2018).

The factors that can improve the reputation of the university according to (Warta 2017, p. 194) are, maintaining and improving the quality of the implementation of the Tridharma of Higher Education in accordance with the vision, mission, and basic values adopted by the institution, consistently implementing good university governance. university governance).

There are two indicators on university reputation according to (Warta, 2017, p. 199), namely, the Tridharma of Higher Education, and good university governance.

\section{RESEARCH METHODS}

This study aims to determine the effect of brand trust and university reputation on purchasing decisions, namely student decisions in choosing the Management Study Program at the UMSU Faculty of Economics and Business. The approach taken in this study is to use an associative 


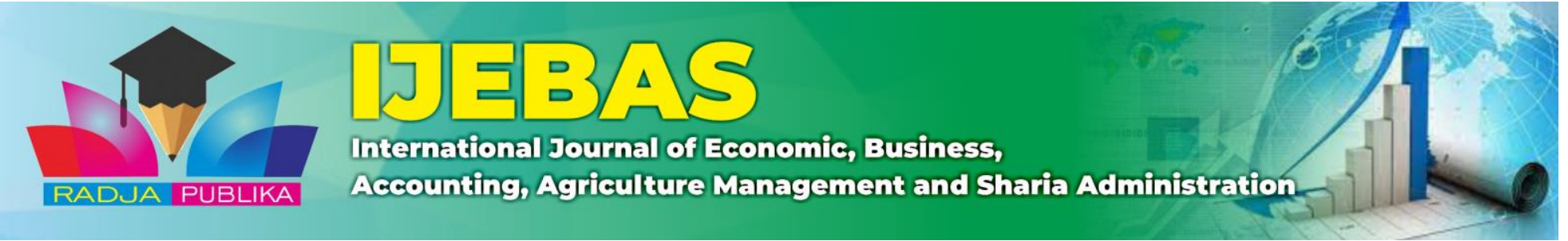

approach, namely research that seeks to examine how a variable has a relationship or relationship with other variables. Sampling was done by non-probability sampling technique, with an incidental sampling approach.

The population in this study were all students of the 2018/2019 UMSU Management Study Program, and the sample used in this study amounted to 126 respondents using the slovin technique. Data was collected by questionnaire method. The data analysis technique was carried out using multiple linear regression, classical assumption test, $t$ test, $F$ test and coefficient of determination. The results showed that the brand trust variable had a significant effect on purchasing decisions, and the university reputation variable had a significant effect on purchasing decisions. Based on the simultaneous test, the variable brand trust and university reputation have a significant effect on purchasing decisions.

\section{RESEARCH RESULTS AND DISCUSSION}

\section{Research result}

This study aims to analyze data derived from data that has been described from previous data based on research instruments that have been validated and have a high level of reliability (reliable).

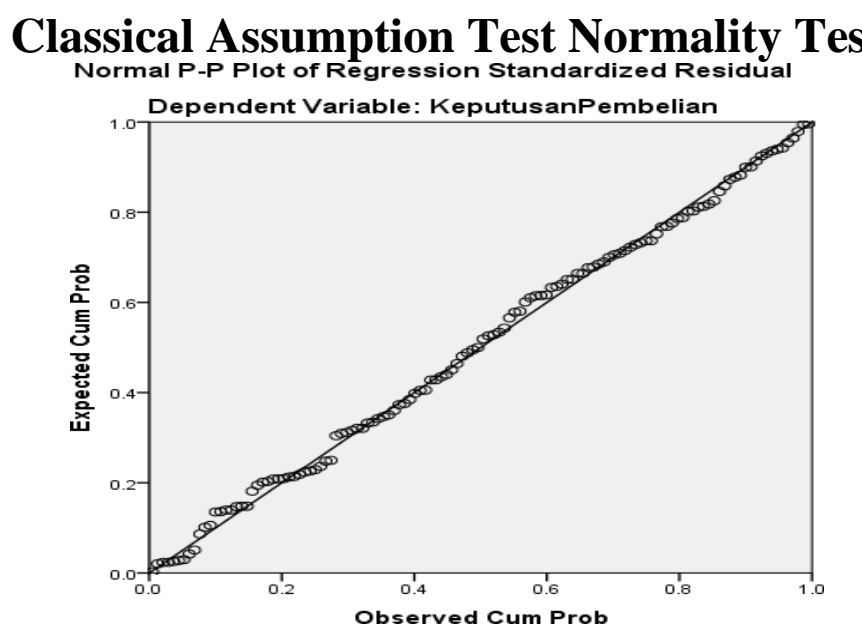

Figure 1

\section{Standardized PP Plot Normality Test}

In the picture of the PP normality test plot of regression standardized residual above, it indicates that the regression model has met the criteria previously stated, so the data in the regression model in this study are tend normal. 
The Effect of Brand Trust and University Reputation on Student's Decision to Choose Management Study Program in The Faculty of Economics and Business Universitas Muhammadiyah Sumatera Utara Nel Arianty, Julita

\section{Heteroscedasticity}

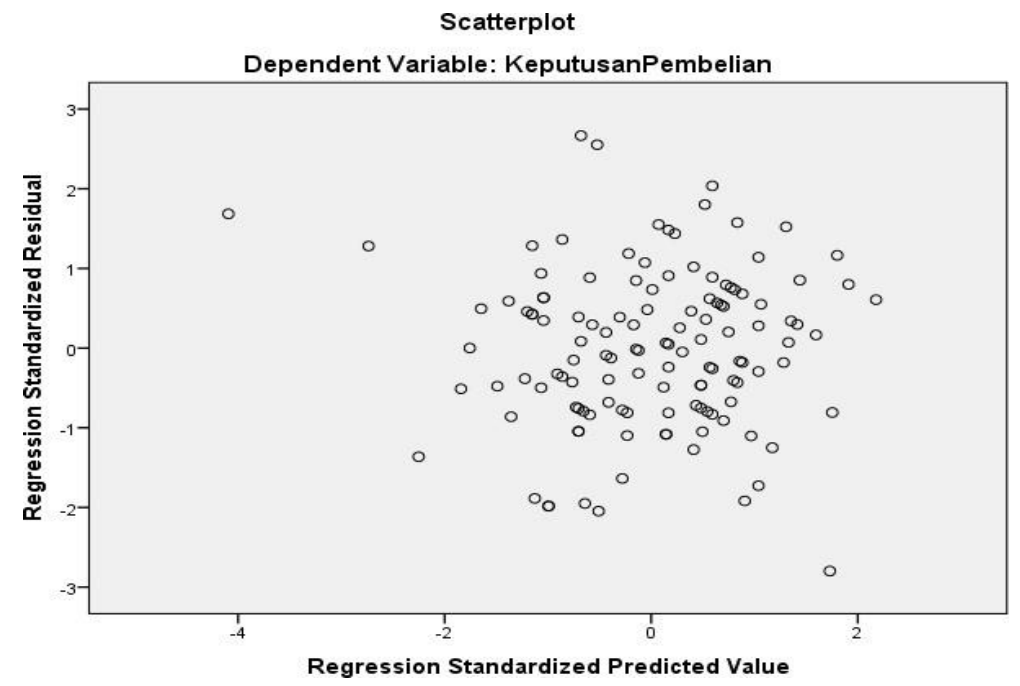

Figure 2

Heteroscedasticity Test Scatterplot

Based on the figure above, it is known that the resulting points are spread out. This shows that this linear regression model is free from heteroscedasticity.

\section{Multicollinearity}

Table 1

Multicollinearity

\begin{tabular}{|c|c|c|c|c|c|c|c|c|c|c|}
\hline \multirow[b]{2}{*}{ Model } & \multicolumn{2}{|c|}{$\begin{array}{l}\text { Unstandardize } \\
\text { d Coefficients }\end{array}$} & \multirow{2}{*}{$\begin{array}{c}\begin{array}{c}\text { Standardized } \\
\text { Coefficients }\end{array} \\
\text { Beta }\end{array}$} & \multirow[b]{2}{*}{$\mathrm{T}$} & \multirow[b]{2}{*}{ Sig. } & \multicolumn{3}{|c|}{ Correlations } & \multicolumn{2}{|c|}{$\begin{array}{c}\text { Collinearity } \\
\text { Statistics }\end{array}$} \\
\hline & B & $\begin{array}{l}\text { Std. } \\
\text { Error }\end{array}$ & & & & $\begin{array}{l}\text { Zero- } \\
\text { order }\end{array}$ & Partial & Part & Tolerance & VIF \\
\hline (Constant) & & & & & & & & & & \\
\hline & 25,475 & 2.873 & & 8.866 & .000 & & & & & \\
\hline Brand Trust & .395 & .105 & .351 & 3.757 & .000 & .539 & .321 & .274 & .611 & 1,638 \\
\hline University Reputation & .335 & .104 & .301 & 3.225 & .002 & .520 & .279 & .235 & .611 & 1,638 \\
\hline
\end{tabular}

a. Dependent Variable: Purchase Decision

Source: SPSS Output Data (2019)

Based on the table above, it is known that multicollinearity shows that the VIF of brand trust is 1.638 which is smaller than five, and the VIF of the university's reputation is 1.638 . Thus it is known that there is no multicollinearity in the data. 


\section{Multiple Linear Regression Analysis}

Table 2

Multiple linear regression

\begin{tabular}{|c|c|c|c|c|c|c|c|c|c|}
\hline \multirow[b]{2}{*}{ Mode } & & \multicolumn{2}{|c|}{$\begin{array}{l}\text { Unstandardized } \\
\text { Coefficients }\end{array}$} & $\begin{array}{l}\text { Standardized } \\
\text { Coefficients }\end{array}$ & \multirow[b]{2}{*}{$\mathrm{T}$} & \multirow[b]{2}{*}{ Sig. } & \multicolumn{3}{|c|}{ Correlations } \\
\hline & & B & Std. Error & Beta & & & $\begin{array}{l}\text { Zero- } \\
\text { order }\end{array}$ & Partial & Part \\
\hline \multirow[t]{4}{*}{1} & (Constant) & 25,475 & 2.873 & & 8.866 & .000 & & & \\
\hline & $\begin{array}{l}\text { Brand } \\
\text { Trust }\end{array}$ & .395 & .105 & .351 & 3.757 & .000 & .539 & .321 & .274 \\
\hline & University & & & & & & & & \\
\hline & $\begin{array}{l}\text { Reputatio } \\
\text { n }\end{array}$ & .335 & (104 & .301 & 3.225 & .002 & .520 & .279 & .235 \\
\hline
\end{tabular}

a. Dependent Variable: Purchase Decision

Source: SPSS Output Data (2019)

Based on the data from the coefficients table above (in the unstandardized coefficients column), it can be seen that the multiple regression equations for the two predictors of the brand trust and university reputation variables are:

\section{Obtained the value of $\mathrm{Y}=25.475+0.395 \mathrm{X} 1+0.335 \mathrm{X} 2$}

The above equation shows that Brand Trust (X1) and University Reputation (X2) have a positive coefficient value, which means that all independent variables in this study have a direct influence on the Purchase Decision variable (Y). Assuming that the Brand Trust coefficient (X1) gives a value of 0.395, which means that if the brand trust is carried out well with the assumption that other independent variables are fixed, the purchase decision will increase. The University Reputation Coefficient (X2) gives a value of 0.335 , which means that if the reputation of the university is improved, assuming the value of other variables is fixed, the purchasing decision variable will also increase.

t test (Partial)

\section{Hypothesis testing}

\section{The Effect of Brand Trust (X1) on Purchase Decisions}

Table 3

T test (hypothesis 1)

\begin{tabular}{|c|c|c|c|c|c|}
\hline \multirow[b]{2}{*}{ Model } & \multicolumn{2}{|c|}{$\begin{array}{c}\text { Unstandardized } \\
\text { Coefficients }\end{array}$} & \multirow{2}{*}{$\begin{array}{c}\begin{array}{c}\text { Standardized } \\
\text { Coefficients }\end{array} \\
\text { Beta }\end{array}$} & \multirow[b]{2}{*}{$\mathrm{T}$} & \multirow[b]{2}{*}{ Sig. } \\
\hline & $\mathrm{B}$ & $\begin{array}{l}\text { Std. } \\
\text { Error }\end{array}$ & & & \\
\hline (Constant) & $\begin{array}{r}25.4 \\
75\end{array}$ & 2.873 & & 8.866 & .000 \\
\hline Brand Trust & .395 & .105 & .351 & 3.757 & .000 \\
\hline University Reputation & .335 & .104 & .301 & 3.225 & .002 \\
\hline
\end{tabular}

Source:SPSS Output Data (2019)

Based on the t-test table data above, it can be seen the value of the coefficients obtained: tcount $=3.757>$ ttable $=1.979$ or sig. $0.000<0.05$. From these results it can be concluded that $\mathrm{H} 0$ is rejected. This shows that there is a significant influence between the brand trust variable (X1) on the purchasing decision variable (Y) students choose the Management Study Program, Faculty of Economics and Business at Muhammadiyah University of North Sumatra. 
The Effect of Brand Trust and University Reputation on Student's Decision to Choose Management Study Program in The Faculty of Economics and Business Universitas Muhammadiyah Sumatera Utara Nel Arianty, Julita

\section{The Effect of University Reputation (X2) on Purchase Decisions (Y) \\ Table 4 \\ T test (hypothesis 2)

\begin{tabular}{|l|r|r|r|r|r|}
\hline \multirow{2}{*}{ Model } & \multicolumn{2}{|c|}{$\begin{array}{c}\text { Unstandardized } \\
\text { Coefficients }\end{array}$} & $\begin{array}{c}\text { Standardized } \\
\text { Coefficients }\end{array}$ & & \\
\cline { 2 - 5 } & \multicolumn{1}{|c|}{$\mathrm{B}$} & $\begin{array}{c}\text { Std. } \\
\text { Error }\end{array}$ & \multicolumn{1}{|c|}{ Beta } & \multicolumn{1}{|c|}{ T } & Sig. \\
\hline (Constant) & 25.4 & 2.873 & & 8.866 & .000 \\
Brand Trust & 75 & .105 & .351 & 3.757 & .000 \\
University Reputation & .395 & .104 & .301 & $\mathbf{3 . 2 2 5}$ & $\mathbf{. 0 0 2}$ \\
\hline
\end{tabular}

Based on the t-test table data above, it can be seen that the coefficient acquisition value is: tcount : $3,225>$ ttable : 1,979 or sig. $0.002<0.05$. From these results it can be concluded that H0 is rejected. This shows that there is a significant influence between the university's reputation variable (X2) on the purchasing decision variable (Y) students choose the Management Study Program, Faculty of Economics and Business at Muhammadiyah University of North Sumatra.

\section{F Test (Simultaneous)}

Table 5 F . Test

ANOVAa

\begin{tabular}{|ll|r|r|r|r|r|}
\hline Model & & Sum of Squares & df & Mean Square & F & Sig. \\
\hline 1 & Regression & 789,247 & 2 & 394,624 & 32,461 & $.000 \mathrm{~b}$ \\
& Residual & 1495.293 & 123 & 12,157 & & \\
& Total & 2284,540 & 125 & & & \\
\hline
\end{tabular}

a. Dependent Variable: Purchase Decision

b. Predictors: (Constant), University Reputation, Brand Trust

Source: SPSS Output Data (2019)

Based on the F test table data with the above criteria, Fcount value is 32.461 , while the Ftable value is 3.070 or with a significant value Ftable $0.000 \mathrm{n}<0.05$ so it can be understood that this value indicates a significant influence between the independent variable $(X)$ on the dependent variable ( $\mathrm{Y})$ or it is understood that there is a significant influence between brand trust variables (X1) and university reputation (X2) on purchasing decisions (Y) students choose the Management Study Program, Faculty of Economics and Business at Muhammadiyah University of North Sumatra.

\section{Coefficient of Determination}

Table 6 Coefficient of Determination Model Summaryb

\begin{tabular}{|l|r|r|r|r|}
\hline Model & $\mathrm{R}$ & $\mathrm{R}$ Square & \multicolumn{1}{c|}{$\begin{array}{c}\text { Adjusted R } \\
\text { Square }\end{array}$} & $\begin{array}{c}\text { Std. Error of the } \\
\text { Estimate }\end{array}$ \\
\hline 1 & $.588 \mathrm{a}$ & .345 & .335 & 3.487 \\
\hline
\end{tabular}

a. Predictors: (Constant), University Reputation, Brand Trust

b. Dependent Variable: Purchase Decision

Source:SPSS Output Data (2019)

Based on the results of the regression test of the coefficient of determination of the summary model in the table above, it can be seen that the coefficient of determination ( $\mathrm{R}$ square) obtained in this study is 0.345 . This means that $34.5 \%$ of the purchasing decision variables can be explained by 
the independent variables, namely brand trust (X1) and university reputation (X2). While the remaining $66.5 \%$ is influenced by other variables that are not included in this study.

\section{DISCUSSION}

\section{Research Results on the Effect of Brand Trust (X1) on Purchase Decisions (Y)}

It can be seen that based on the results of testing the research hypothesis about the effect of the brand trust variable on purchasing decisions, the ttable results are 1.979, and the tcount value is 3.757 with the meaning that tcount $>$ ttable with a significant value of $0.000<0.05$. From these results it can be concluded that $\mathrm{H} 0$ is rejected. This shows that there is a significant influence between the brand trust variables on the purchasing decision variables of students choosing the Management Study Program at the Faculty of Economics and Business, Muhammadiyah University, North Sumatra.

The results of this study are in line with previous research conducted by Suryawardana and Endang (2015, p.265) which states that trust has a positive effect on purchasing decisions. Next is the results of research conducted by Adiwidjaja \& Tarigan (2017) with the results of research that brand trust has a positive effect on purchasing decisions. Likewise, the results of research conducted by (Amron, 2018) state that brand trust has a significant effect on purchasing positively and can affect consumer decisions in determining the purchase of MPV cars.

\section{Research Results on the Effect of University Reputation (X2) on Purchase Decisions (Y)}

In the results of testing the research hypothesis about the effect of the university's reputation variable $(\mathrm{X} 2)$ on purchasing decisions $(\mathrm{Y})$ it was obtained ttable of 1,979 , and the acquisition of tcount of 3,225 with the meaning that tcount $>$ ttable with a significant value of $0.002<0.05$. the results concluded that $\mathrm{H} 0$ was rejected. This shows that there is a significant influence between the university's reputation variable on the purchasing decision variable of students choosing the Management Study Program at the Faculty of Economics and Business, Muhammadiyah University of North Sumatra.

The results of this study are supported by previous research conducted by Ansari, Hurriyati, Gaffar, Adi, \& Amanah, (2017, p. 4) which states that the positive university reputation variable has a significant effect on purchasing decisions. Furthermore, the results of this study are in line with previous research conducted by Suryawardana and Endang (2015) which stated that the company's reputation had a positive effect on purchasing decisions. The results of research conducted by Wibowo (2014) stated that the implication of a good university reputation is to encourage potential students to choose the university as their main priority.

\section{Research Results on the Effect of Brand Trust (X1) and University Reputation (X2) on Purchase Decisions (Y)}

Through testing the hypothesis about the effect through the F test above, it can be seen that the Fcount value is 32.461 , while Ftable is 3.070 with a significant level of 0.05 .

The results of this study are in line with previous research conducted by Suryawardana and Endang $(2015$, p.) that the influence of brand trust and university reputation together has a positive and significant effect on purchasing decisions. The results of research conducted by Wibowo (2014) stated that the implication of a good university reputation is to encourage potential students to choose the university as their main priority.

\section{CONCLUSION}

There is a significant influence between the brand trust variables on purchasing decisions (student decisions) choosing the Management Study Program at the Faculty of Economics and Business, Muhammadiyah University of North Sumatra. There is a significant influence between the university's reputation variable on purchasing decisions (student decisions) choosing the 
The Effect of Brand Trust and University Reputation on Student's Decision to Choose Management Study Program in The Faculty of Economics and Business Universitas Muhammadiyah Sumatera Utara Nel Arianty, Julita

Management Study Program at the Faculty of Economics and Business, Muhammadiyah University of North Sumatra. The existence of a significant influence between the variable brand trust and university reputation has a significant effect on purchasing decisions (student decisions) to choose the Management Study Program at the Faculty of Economics and Business, Muhammadiyah University of North Sumatra.

\section{REFERENCE}

Adiwidjaja, A. J., \& Tarigan, Z. J. (2017). Pengaruh Barand Image Dan Brand Trust Terhadap Keputusan Pembelian Sepatu Converse. Jurnal Agora, 5 (3), 1-9.

Amron, A. (2018). The Influence of Brand Image, Brand Trust, Product Quality, and Price on the Consumer's Buying Decision of MPV Cars. European Scientific Journal, 14 (3), 228-239.

Ansari, D., Hurriyati, R., Gaffar, V., Adi, L., \& Amanah, D. (2017). Pengaruh Reputasi Universitas Terhadap Keputusan Mahasiswa Memilih Studi Di Universitas Islam Sumatra Utara. Forum Manajemen Indonesia (FMI 9), 1 (1), 1-13.

Arianty, N., Laili, P., Christiana, I., \& Jasin, H. (2016). Manajemen Pemasaran. Medan, Sumatra Utara: Perdana Publishing. . (2016). Pengaruh Promosi Dan Merek Terhadap Keputusan Pembelian. 2 (1), 77 78.

Bambang, R. R. (2017). Manajemen Resiko, Prinsip, Penerapan, dan Penelitian. Jakarta Selatan: Salemba Empat.

Bastian, D. A. (2014). Analisa Pengaruh Citra Merek (Brand Image) dan Kepercayaan Merek (Brand Trust) Terhadap Loyalitas Merek (Brand Loyalty) ADES PT. Ades Alfindo Putra Setia. Jurnal Manajemen Pemasaran Petra, 2 (1), 1-9.

Dedi, A. H. (2015). Analisis Faktor-Faktor Yang Mempengaruhi Keputusan Pembelian Konsumen Di Pajak USU (Pajus) Medan. Jurnal Keuangan dan Bisnis, 7 (3), 227- 241.

Desy, E. (2016). Pengaruh Brand Image, Lokasi Dan Fasilitas Terhadap Keputusan Mahasiswa Memilih Universitas Pancabudi. Jurnal Ilmiah Dunia Ilmu, 2 (1), 25-39.

Fahmi, I. (2016). Prilaku Konsumen Teori dan Aplikasi. Bandung: Alfabeta.

Fauziyah, S. (2016). Pengaruh Brand Trust Dan Brand Equity Terhadap Loyalitas Konsumen Pada Produk Kosmetik Wardah (Survey Konsumen Pada PT. Paragon Technology And Innovation Cabang Pekan Baru). Jom Fisip, 3 (2), 1-9.

Handayani, A. (2017). Analisis Bauran Pemasaran Terhadap Keputusan Mahasiswa Memilih Program Studi Di Fakultaas Ekonomi. Publikasi Ilmiah, 1 (1), 1-11.

Harahap, D. A. (2015). Analisis Faktor Yang Mempengaruhi Keputusan Pembelian Konsumen Di Pajak USU (PAJUS) Medan. Jurnal Keuangan dan Bisnis, 7 (3), 227- 241.

Khaddafi, M. ., Aryani, R. A., \& Heikal, M. . (2021). THE EFFECT OF FINANCIAL KNOWLEDGE AND PERSONAL NET INCOME ON THE FINANCIAL BEHAVIOR OF MALIKUSSALEH UNIVERSITY EMPLOYEES WITH LOCUS OF CONTROL AS MODERATING VARIABLES. International Journal of Economic, Business, Accounting, Agriculture Management and Sharia Administration (IJEBAS), 1(1), 1-13. https://doi.org/10.54443/ijebas.v1i1.1

Kelvi. (2018). Analisis Pengaruh Promosi, Biaya Studi, Fasilitas Perkuliahan, Dan Kualitas Pelayanan Terhadap Keputusan Mahasiswa Untuk Kuliah Di Sekolah Tinggi Teknik Surabaya. Jurnal Manajemen Kinerja, 4 (1), 46-55.

Putra, E., Yunus, M., \& Sulaiman. (2015). Pengaruh Bauran Pemasaran Jasa Terhadap Kepercayaan Merek (Brand Trust) Dan Dampakanya Pada Keputusan Mahasiswa Memilih Kuliah Di Politeknik Aceh. Jurnal Manajemen Paca Sarjana Universitas Syiah Kuala, 4 (1), 174-185.

Radiman, Gunawan, A., Wahyuni, S. F., \& Jufrizen. (2018). The Effect of Marketing Mix, Service

132 International Journal of Economic, Business, Accounting, Agriculture Management and Sharia Administration |IJEBAS E-ISSN: 2808-4713 | https://radjapublika.com/index.php/IJEBAS 


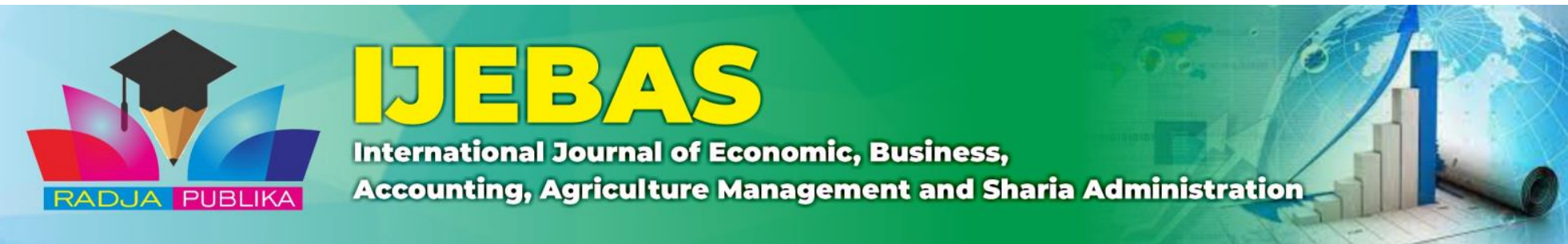

Quality, Islamic Values and Institutional Image on Students' Satisfaction and Loyalty. Expert Journal of Marketing, 6 (2), 95-105.

Rahmawati, R. (2017). Hubungan Antara Reputasi Perusahaan Dengan Kepercayaan Pada Konsumen Ekspedisi X. Publikasi Ilmiah, 1 (1), 1-14.

Rustam, B. R. (2017). Manajemen Resiko Prinsip, Penerapan, dan Penelitian. Jakarta Selatan: Salemba Empat.

Sugiyono, P. D. (2017). Metode Penelitian Kuantitatif, Kualitatif, dan R\&D. Bandung: Alfabeta, Bandung.

Suryawardana, E., \& Endang, T. (2015). Analisis Pengaruh Reputasi, Kualitas Pelayanan Dan KepercayaanTerhadap Keputusan Pembelian Pada Stasiun Pengisian Bahan Bakar Umum (SPBU) Di Kota Semarang. J. Dinamika Sosbud, 17 (2), 258-269.

Warta, W. (2017). Manajemen Reputasi. In I. T. Nugraha (Ed.). Bandung, Jawa Barat: Simbiosa Rekatama Media.

Wibowo, A. J. (2009). Pengaruh Kualitas Layanan, Reputasi, dan Nilai Layanan Perguruan Tinggi Terhadap Kepuasan Mahasiswa. Bina Ekonomi Majalah Ilmiah Fakultas Ekonomi Unpar, 13 (2), 59-73.

(2014). Kinerja Riset Universitas, Reputasi Universitas, Dan Pilihan Universitas: Sebuah Telaah Sistematis. Jurnal Manajemen, 13 (2), 91-114.

Www.wikepedia. (2018, Oktober). Universitas Muhammadiyah Sumatra Utara. Retrieved from http://id.wikipedia.org/wiki/Universitas_Muhammadiyah_Sumatera_Utara

Www.Wikipedia.Org. (2018). Perguruan Tinggi. Retrieved from https://id.wikipedia.org/wiki/Perguruan_tinggi 
Volumes 1 No 2 (2021)

The Effect of Brand Trust and University Reputation on Student's Decision to Choose Management Study Program in The Faculty of Economics and Business Universitas Muhammadiyah Sumatera Utara Nel Arianty, Julita 